\title{
Em busca de patamares mais elevados
}

\author{
In search of higher levels
}

Embora este seja o segundo número do volume 14 da Revista Brasileira de Medicina do Trabalho (RBMT), ele é o primeiro número publicado na nova gestão da Associação Nacional de Medicina do Trabalho (ANAMT) (2016-2019), sob a liderança da Profa Marcia Bandini, que teve a iniciativa de "ressuscitar" o idealizador e primeiro editor da revista, fundada em 2003, convidando-o, ou melhor, convidando-me para ser seu editor-chefe.

Honrado pela deferência, apressei-me a me inteirar dos compromissos públicos de campanha da Prof. ${ }^{a}$ Marcia Bandini, renovados no discurso de posse no último dia do grandioso $16^{\circ}$ Congresso da ANAMT, no que diz respeito à revista e das propostas de seu fortalecimento e desenvolvimento, em busca de patamares mais elevados. Aceitei o desafio, sobretudo após reler o "Editorial" que escrevi em 2003, para o primeiro número da então nascente RBMT, a qual — escrevia eu — "traz os genes do contínuo rejuvenescimento e de uma vida permanente e eterna, que seus idealizadores e editores bem gostariam de também ter".

Em boa hora, a nova direção da ANAMT coloca a RBMT entre suas prioridades e fixa metas, prazos e indicadores e, assim, estamos todos engajados nesse esforço coletivo pactuado. Há que se reconhecer que querer patamares mais ambiciosos é menos impossível quando o ponto de partida já é elevado, e para isso é necessário e oportuno reconhecer e creditar às gestões que nos antecederam, por justo e merecido.

Porém, doravante, há patamares mais elevados a ser alcançados, num esforço de melhoria contínua — termo consagrado e até banalizado, mas que aqui se aplica ressignificado, talvez, como eu... Pois bem, entre as providências concretas destacam-se o aumento da periodicidade da RBMT, que, de semestral, passará a ser quadrimestral este ano, e a partir de 2017 será trimestral. O alinhamento desta nova gestão e direção da RBMT com as recomendações da LILACS e de outros sistemas de indexação (a SciELO, por exemplo) também inclui o aumento do número de artigos originais, a renovação, descentralização e internacionalização da Editoria Associada e do Conselho Editorial, como poderá ser visto aqui na primeira página deste número.

Com o aumento de artigos publicados, o aumento da periodicidade (de dois para quatro números por ano) e a internacionalização da Editoria e do Conselho Editorial, pretende-se não apenas atrair mais autores e mais leitores, como, também, encurtar significativamente os prazos entre submissão, análise, emissão de pareceres, devolutivas e eventual publicação efetiva, diminuindo, portanto, a "latência" do processo, o que também é de interesse de todos, principalmente dos autores.

Para aperfeiçoar esse processo, a atual direção da ANAMT está contratando uma plataforma de sistema de gestão online de manuscritos, que permitirá não apenas encurtar os tempos como também facilitar o acesso de todas as partes interessadas (autores, gestores da revista, revisores e pareceristas), conferindo, ademais, transparência e agilidade. Da mesma forma, está sendo desenvolvido um site bilíngue, especialmente dedicado à RBMT, para aumentar a visibilidade de nossa revista no cenário nacional e internacional, com ferramentas de busca de artigos, publicação de artigos ahead of print, entre outros recursos, a exemplo das principais revistas científicas do mundo.

Enfim, são boas notícias que queremos compartilhar com todos e todas. Servem elas, também, para (re)convidar e atrair pessoas como você para serem parceiras na autoria e na submissão de trabalhos em nossa revista, além de colaboradores, divulgadores, leitores, amigos, enfim, tudo aquilo que esta gestão valoriza e busca. Bem-vinda e bem-vindo!

Prof. René Mendes

Editor-Chefe

DOI: 10.5327/Z1679-44352016v14n2ED 